\title{
Public policies in the First District of Bucharest - Sustainable solutions for increasing energy efficiency
}

\author{
Răzvan-Aurelian MUNTEANU \\ Bucharest University of Economic Studies, Bucharest, Romania \\ razvanmunteanu2009@gmail.com
}

\begin{abstract}
The paper represents an analysis of the public policies implemented in the First District of Bucharest related to the energy efficiency. Energy represents a strategic factor for the socio-economic development of Romania and finding the best solutions for increasing energy efficiency will contribute to the objectives for durability and competitiveness in the European Union. The importance of the theme is given by the requirement of the European Union through Energy Efficiency Directive that require member states to set up plans at every three years and evaluate the progress towards energy efficiency annually. Also, for the next period, 2021-2030, all member states must elaborate the 10-year integrated national energy and climate plan (NECP), presenting the solutions in order to meet the different targets for 2030, including energy efficiency. The objective of the article is to find the best solutions for increasing the energy efficiency, having as case study the 1-st District of Bucharest. The author is presenting three solutions, as follows: multistorey thermal rehabilitation, domestic elevators modernization, individual houses thermal rehabilitation. The impact of the solutions presented in the paper are the following: decrease of energy consumption, decrease of $\mathrm{CO}_{2}$ emissions, safety increase.
\end{abstract}

Keywords: public policies, energy efficiency, thermal rehabilitation.

\section{Introduction}

Energy represents a strategic factor for the socio-economic development and finding the best solutions for increasing energy efficiency will contribute to the objectives for durability and competitiveness in the European Union. Since 2018, European legislation was directed by Performance of Buildings Directive 2010/31/EU (EPBD) and the Energy Efficiency Directive 2012/27/EU, according to which $35 \%$ of the buildings from Europe have more than fifth years and were responsible for almost $40 \%$ of the energy consumption and $36 \%$ of the CO2 emissions.

The same directive mentions that an efficient, prudent, rational and sustainable use of energy is applied, to petroleum products, natural gas and solid fuels, which represent essential sources of energy, but which are also the main sources of carbon dioxide emissions.

The EU and national governments have set clear objectives to guide European environment policy until 2020 and a vision beyond that, of where to be by 2050, with the support of dedicated research programs, legislation and funding, the goal:

- protect, conserve and enhance the EU's natural capital;

- turn the EU into a resource-efficient, green, and competitive low-carbon economy;

- safeguard EU citizens from environment-related pressures and risks to health and wellbeing;

According with The Intergovernmental Panel on Climate Change (IPCC) Human activities are estimated to have caused approximately $1.0^{\circ} \mathrm{C}$ of global warming above pre-industrial levels, with a likely range of $0.8^{\circ} \mathrm{C}$ to $1.2^{\circ} \mathrm{C}$. Global warming is likely to reach $1.5^{\circ} \mathrm{C}$ between 2030 and 2052 if it continues to increase at the current rate.

In order to increase the energy efficiency, European Union and member states finance programs for renovation of multilevel buildings. As Hamburg A., Kuusk K., Mikola A. and Kalamees $\mathrm{T}$ are mentioning, some previous studies have shown that energy renovation is a cost- 
efficient way to improve indoor climates and achieve energy savings up to $80 \%$. They mention that for residential buildings, the most cost-effective renovation measure is additional insulation on the external walls. In addition to the insulation of the building envelope, renovation must include the renewing of building heating and ventilation systems.

\section{Methodology}

PICBE | 41

The objective of this paper is to identify solutions for public administration in order to increase the energy efficiency in buildings. In this line, in the first part of the study, we analyze the energy sector from European Union through quantitative and qualitative indicators like: consumption of energy, share of energy products in total final energy consumption in European Union, share of energy from renewable sources from European Union and Romania. These indicators are taken from the European and national statistical databases (National Institute of Statistics) and interpreted with the help of statistical indicators such as the mean and the average annual growth rate.

In the second part of the study we propose 3 solutions for increasing the energy efficiency in the First District of Bucharest. The data were collected from the database of the local administration of the district and were analyzed in order to calculate the total investment. Also, we have identified local decisions which are transposed in the public policies for increasing energy efficiency in the buildings. The impact of the proposed measures was determined by calculating the level of $\mathrm{CO} 2$ emissions.

\section{Results and discussions}

\section{Energy consumption in European Union}

In order to ensure to consumers a sustainable, affordable and secure energy, European Commission has developed a strategy for an Energy Union, that has the following objectives: energy security, solidarity and trust; a fully-integrated internal energy market; energy efficiency contributing to moderation of demand; decarbonizing the economy; combat energy poverty, research, innovation and competitiveness.

The Fourth Report of the State of the Energy Union is mentioning that the union is having a positive impact upon economy and employment because, beyond of the important role for policy for energy and climate change, the union is about a structural modernization of the European economy. Eurostat states that two thirds from the total energy available from European Union is used by end users, that means households, industry and agriculture. 


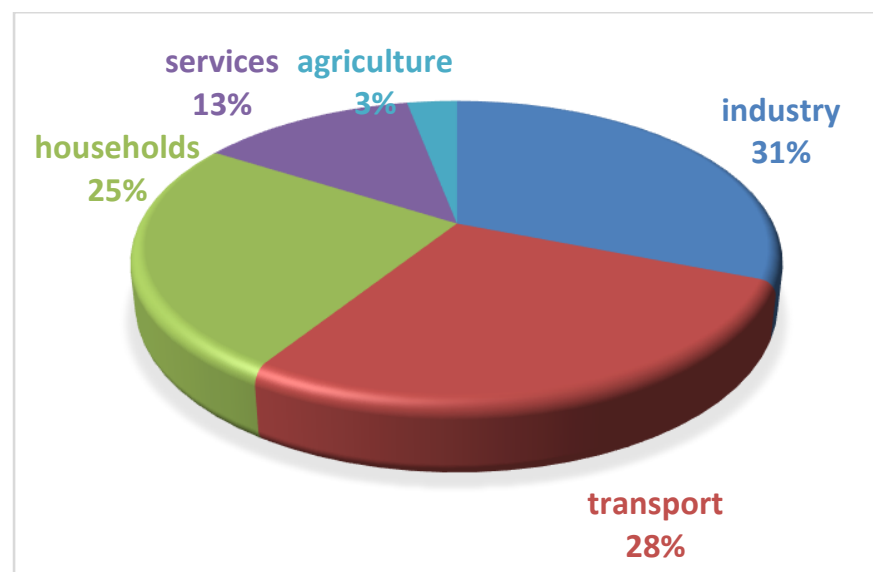

Fig. no.1. Consumption of energy by sector in European Union, 2017 (\%)

PICBE | 42

Source: Eurostat

In figure no. 1 it is presented the share of the energy consumption by each sector in European Union. We can notice that industry consumes $31 \%$ from the total energy consumption, followed by transport with $28 \%$ and households with $25 \%$.

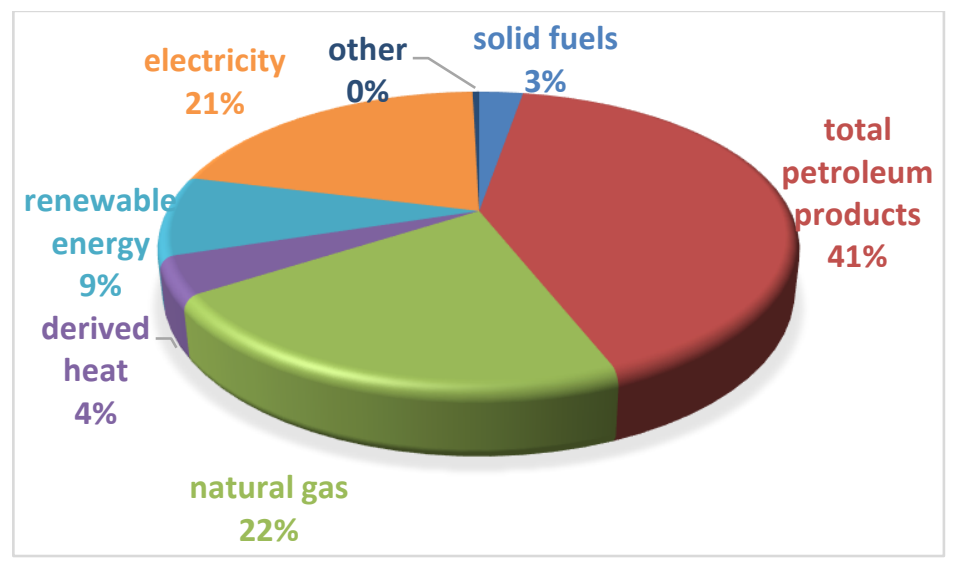

Fig. no. 2. Share of energy products in total final energy consumption in European Union in 2017

Source: Eurostat

Analyzing the data from Eurostat, we can see that in European Union, the final energy consumption is still dependent of petroleum products (includes petroleum, heating oil, diesel fuel), representing $41 \%$ in 2017. As well, a very important share is dedicated to natural gas and electricity (includes wind power, hydroelectricity, solar photovoltaic) accounting $43 \%$ together. The renewable energy (includes wood, biogas or solar thermal) represents only $9 \%$, but still, a big share of renewable is included in electricity sources. The derived heat and solid fuels are used for warming spaces and industrial process and mostly include coal as main source. 


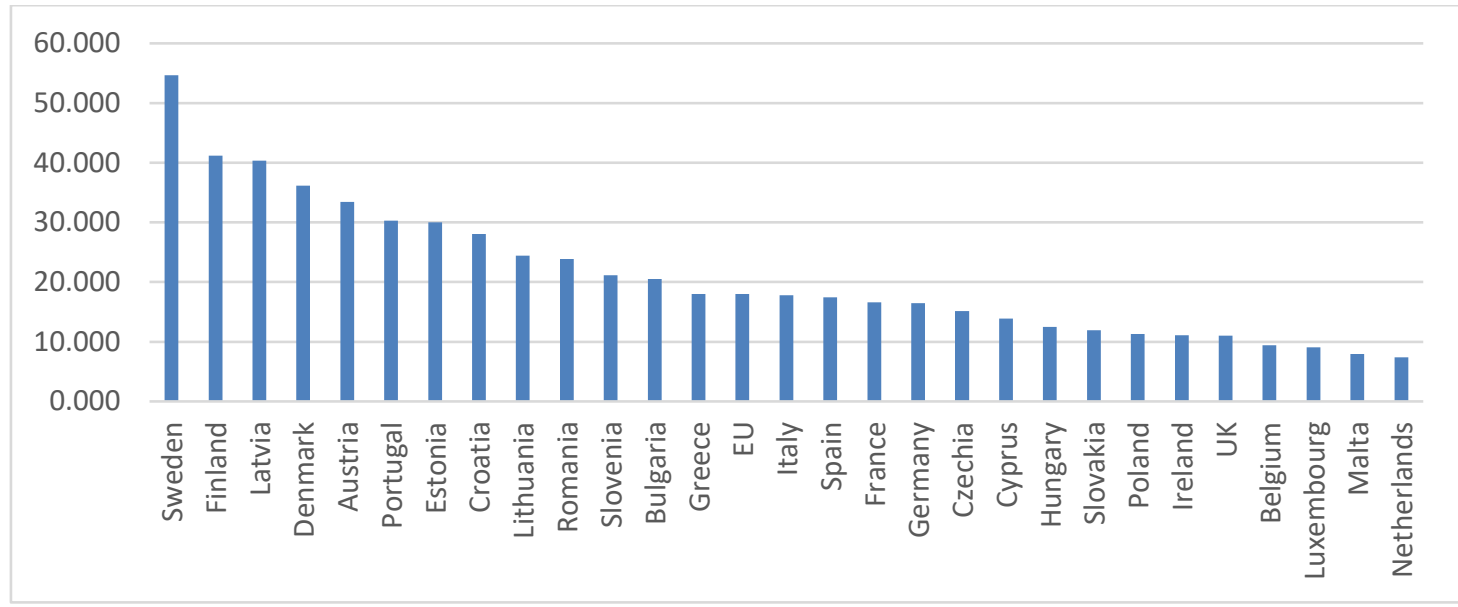

PICBE $\mid 43$

Fig. no. 3. Share of energy from renewable sources in European Union countries, in 2018 (\%)

Source: Eurostat

Miller L. and Carriveau R. are mentioning that future power systems are likely to be very different from those operating currently and there will be a substantially increased proportion of renewable energy, spurred by climate change targets and market trends.

In December 2018, European Union has revised the Renewable Energy Directive that requires member states to fulfill at least $32 \%$ from the total consumption of energy with renewable energy by 2030 .

In 2018, the average share of energy from renewable sources was 17,98\% in European Union. The highest share of energy from renewable sources is used by Sweden, representing $54,64 \%$ of total use of energy. Sweden is leader in European Union for this indicator due to the government policies that promoted the use of energy from renewable sources, like the green electricity certification. As Swedish Energy Agency is mentioning, they had a high increase, starting 1990 the use of energy from renewable sources represented 33\%, while in 2017 is 54,4\% and the target is $100 \%$ by 2040 . Romania records $23,86 \%$ at this indicator being located on the 10 -th place from European Union.

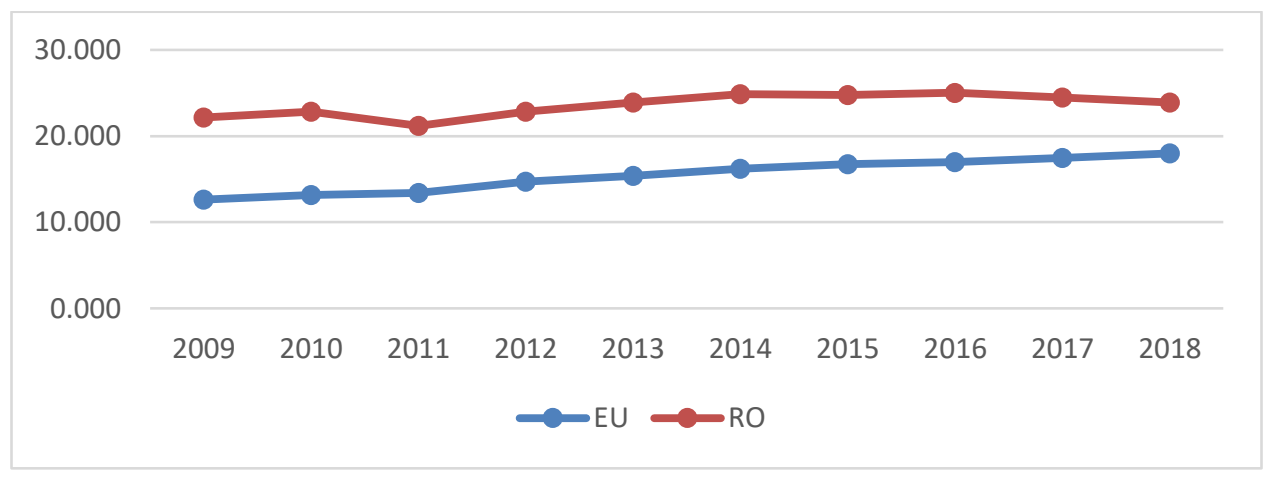

Fig. no. 4. Share of energy from renewable sources from Romania and European Union, in the period $2009-2018(\%)$

Source: Eurostat 


\section{Public policies in the First District of Bucharest for increasing energy efficiency}

Since 2007, Romania is member of the European Union. With a total population of 19,5 million inhabitants, Romania ranks the 7-th place in European Union (having more than 512 mil. inhabitants). The Romanian policy regarding energy efficiency is based on the European Union fundamentals: durability, competitiveness and security. All the local administrations must lead their efforts in promoting measures for increasing the energy efficiency in order to fulfill the EU requirements. In this matter, the authorities from First District of Bucharest, located in the northwest of the capital and having the highest incomes from all six districts, are developing programs like Thermal Rehabilitated Program.

Starting 2009, the District 1 Municipality of Bucharest has implemented a program entitled Thermal Rehabilitated Program that is financed from the European Investments Bank and local budget. The program is financing the following actions:

- thermal insulation of the exterior walls of the block;

- replacing the windows of the entire block and the existing exterior doors with some qualitative upper ones, which will reduce energy losses;

- thermo-waterproofing of the roofs or of the terrace / thermal insulation of the floors above the last level, in case of the existence of the snake;

- thermal insulation of the floor above the basement, whereby designing the block are provided apartments on the ground floor;

- disassembly of the installations and equipment on the facades and terrace of the block of flats as well as their replacement after the thermal insulation works;

- restoration work for tire finishes.

\subsection{Thermal Rehabilitated Program for multilevel buildings}

Through this program, between 2009 and 2019, in District 1 Municipality of Bucharest 60.000 apartments from 1020 multilevel buildings have been fully thermic rehabilitated. The target of the program is to close the Thermal Rehabilitation Program (TRP) for all multilevel-dwellings in total 1120 units, by year 2020, having as main impact reducing the level of CO2 emissions by around 92,000 tones/year, as well as the inhabitants save more than $30 \%$ of the costs with the maintenance bill. The buildings were monitored for 5 years and the dates have been collected from the monthly bills.

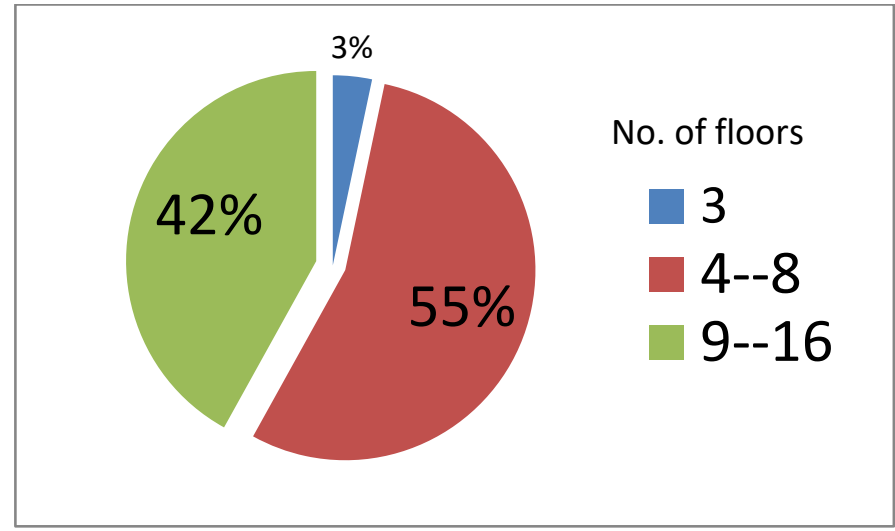

Fig. no. 5. Distribution of multilevel buildings according to the numbers of floors (from a total of 627 buildings in TRP 1)

Source: author`s calculations, data from District 1 Municipality 
No. of buildings

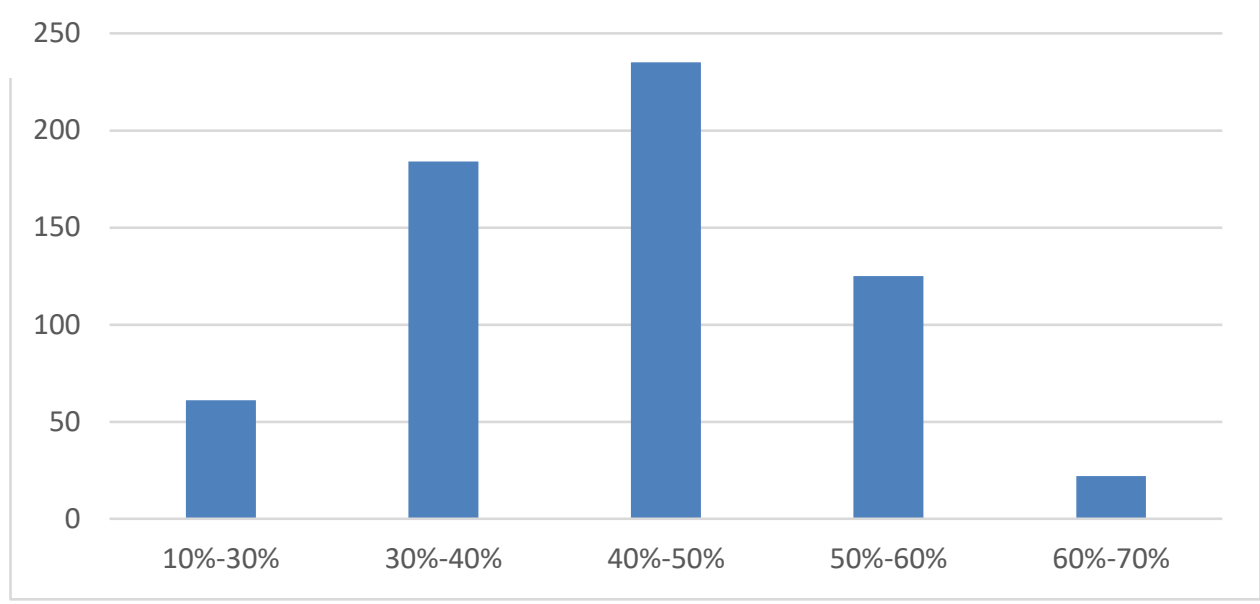

PICBE $\mid 45$

Fig. no. 6. The decreasing level of $\mathrm{CO} 2$ emissions after Thermal Rehabilitated Program (sample of 627 buildings)

Source: author `s calculations, data from District 1 Municipality

The carbon dioxide is one of the major sources of the greenhouse gas worldwide and accounts, in 2016, 35,7 billion tons, representing 4,79 tons/capita, according to world meters of $\mathrm{CO} 2$. The main sources of burning fossil fuel are the followings: power industry $(38,5 \%)$, other industrial processes $(21,2 \%)$, transportation $(20,9 \%)$, buildings $(9,4 \%)$ etc. Buildings represent $9,4 \%$ from the $\mathrm{CO} 2$ emissions worldwide and in this category are included both residential and commercial buildings. The emissions for this category come especially from heating of the buildings and waste management.

Analyzing the impact of the program through a sample of 627 buildings, we can see that the decreasing level of $\mathrm{CO} 2$ emissions is distributed as follows: the highest decrease $(60-70 \%)$ was recorded in 22 buildings, followed by $50 \%-70 \%$ for 125 buildings, $40 \%-50 \%$ for 235 buildings, $30 \%-40 \%$ for 126 buildings and 10\%-30\% for 61 buildings.

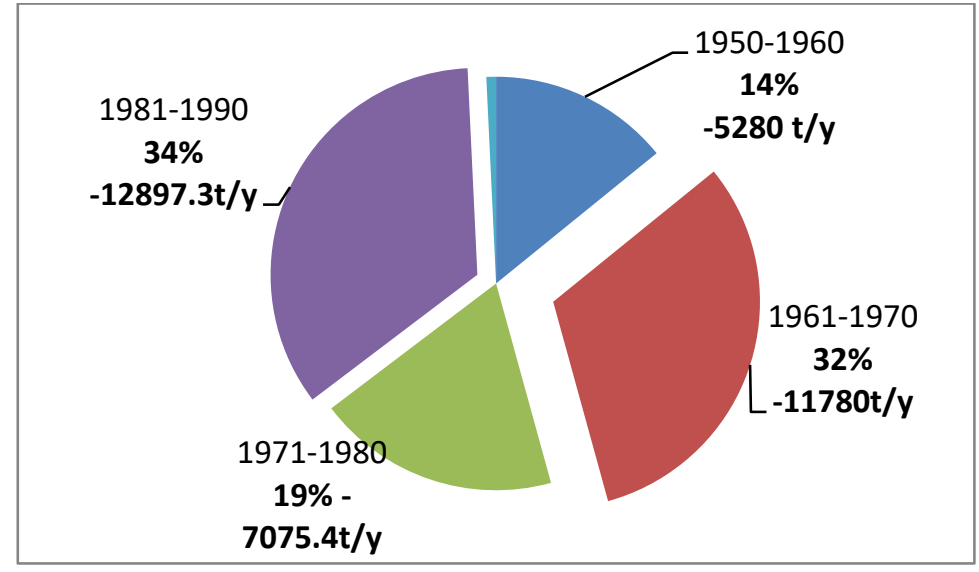

Fig. no. 7. The decreasing level of $\mathrm{CO} 2$ emissions in tones/year depending on the construction period (sample of 627 blocks)

Source: author 's calculations, data from District 1 Municipality 
The impact of the program, for a sample of the same 627 buildings, show a decreasing with 37.032 tons/year of the CO2 emissions, concentrated in the buildings built between 1981-1990 (34\%) and between 1961-1970 (32\%).

\subsection{Thermal rehabilitation of individual houses}

In order to increase the energy efficiency, it is important to take into account not only the multilevel buildings, but individual houses as well. The need of rehabilitation of the individual houses is given by the following problems that are facing the inhabitants from the District 1 of Bucharest: high bills for heating, hot waters and lighting; high $\mathrm{CO} 2$ emissions; low market value of the houses; poor urban landscape; low quality of life, social inequity; degradation of welfare etc.

The main proposal of the District 1 Municipality of Bucharest is to design a pilot project program for 50 houses. The pilot project program consists in financing the thermal rehabilitation works of facades, thermal rehabilitation works of the heating system and installation of alternative energy generation systems from renewable sources in individual houses. The goal of the pilot program is to test, to learn and to adapt the best solutions and then to extend it to all eligible individual houses from District 1 . The houses, in the pilot project, are selected by 8 criteria, like year of construction, land distribution, size of maximum 160 sqm etc. From 2100 requests, only 1470 were eligible representing only $70 \%$ of the total request. The pilot project involves an estimated number of 50 individual houses, as follows:

Table no. 1. Distribution of the houses in the pilot project by heated area

\begin{tabular}{|c|c|c|c|}
\hline \multicolumn{3}{|c|}{ Heated area } & \multirow{2}{*}{$\begin{array}{l}\text { Total } \\
\text { no of building }\end{array}$} \\
\hline 60-85 sqm & 85-110sqm & $110-135$ & \\
\hline 808 & 412 & 250 & 1470 \\
\hline $55 \%$ & $28 \%$ & $17 \%$ & $100 \%$ \\
\hline \multicolumn{3}{|c|}{ Estimated distribution of houses in pilot } & \\
\hline 27 & 14 & 9 & 50 \\
\hline
\end{tabular}

Source: author's calculations, data from District 1 Municipality

Table no.2. Total estimated cost for the pilot project

\begin{tabular}{|l|l|l|l|l|l|}
\hline \multirow{2}{*}{ No of buildings } & \multicolumn{3}{|c|}{ Heated area/ no of houses } & Turot no VAT & $\begin{array}{l}\text { Total } \\
\text { inclusiv VAT }\end{array}$ \\
\cline { 2 - 6 } & $\begin{array}{c}60-85 \mathrm{sqm} / 27 \\
\text { units }\end{array}$ & $\begin{array}{c}85-110 \mathrm{sqm} / 14 \\
\text { units }\end{array}$ & $\begin{array}{c}110-135 / 9 \\
\text { units }\end{array}$ & Total no Vual project \\
\hline $\begin{array}{l}\text { Total preparation } \\
\text { prepal }\end{array}$ & 32340 & 18956 & 13788 & 65084 & 77449.96 \\
\hline $\begin{array}{l}\text { Total cost for } \\
\text { basic } \\
\text { investment }\end{array}$ & 368847 & 223160 & 166914 & 758921 & 903115.99 \\
\hline Total & 401187 & 242116 & 180702 & 824005 & 980565.95 \\
\hline
\end{tabular}

Source: author 's calculations, data from District 1 Municipality

Total investment value, respectively the general estimate, includes three main cost categories: design and technical assistance, works and supervising. The total investment for the pilot project of 50 houses accounts 980.565,95 Euro, that represents almost 60 million Euro for all the 3000 
individual estimated houses, with direct impact in decreasing the energy consumption, increasing the value of the houses, combat energy poverty for families with low income and social equity for citizens from individual houses like multilevel buildings.

\subsection{Domestic elevators modernization}

The energy efficiency program involves financing a set of activities of:

PICBE $\mid 47$

1. replacement/repair works, depending on the case, of the winch motor, traction cables, considering the length specified in the technical book of each elevator, of the structure for the motor and of the relay controller, as the case may be, rods, springs, traction cable clamps, speed limiters but also of the speed limiting cable and the cable tensioner.

2. replacement/repair of the control panel with a microprocessor panel and frequency converter, of the transducers (sensors for station counting and leveling), of the magnets, level control boxes and from the control box with LED or LCD and Braille marking for the buttons, cabin flexible cable (strap / ribbon type), doors' cable, line end switch with reel but also, of the mushroom switch

3. replacing the exterior doors with automated/semiautomated doors, both for wells with reinforced concrete structure and for the ones with a metalic structure but metalic for the cabin.

The inventory includes a total number of 834 entrances in buildings from District 1 of Bucharest with a total number of 902 elevators.

Table no. 3. Number of elevators by height regime

\begin{tabular}{|l|l|l|l|l|c|}
\hline $\begin{array}{l}\text { Height } \\
\text { regime }\end{array}$ & $\begin{array}{l}\text { No } \\
\text { entrance }\end{array}$ & $\begin{array}{l}\text { No } \\
\text { entrance } \\
\text { using the } \\
\text { adjacent } \\
\text { entrance }\end{array}$ & $\begin{array}{l}\text { No } \\
\text { entrance } \\
\text { with 1 } \\
\text { elevator }\end{array}$ & $\begin{array}{l}\text { No } \\
\text { entrance } \\
\text { with 2 } \\
\text { elevators }\end{array}$ & $\begin{array}{l}\text { No of } \\
\text { elevators }\end{array}$ \\
\hline S+P+5E & 4 & 0 & 4 & 0 & 4 \\
\hline S+P+6E & 26 & 0 & 25 & 1 & 27 \\
\hline S+P+7E & 147 & 0 & 146 & 1 & 148 \\
\hline S+P+8E & 244 & 1 & 234 & 9 & 252 \\
\hline S+P+9E & 125 & 2 & 113 & 10 & 133 \\
\hline S+P+10E & 225 & 0 & 195 & 30 & 255 \\
\hline S+P+11E & 44 & 0 & 35 & 9 & 53 \\
\hline S+P+12E & 13 & 0 & 6 & 7 & 20 \\
\hline S+P+13E & 2 & 0 & 2 & 0 & 2 \\
\hline S+P+14E & 2 & 0 & 0 & 2 & 4 \\
\hline S+P+15E & 1 & 0 & 0 & 1 & 2 \\
\hline S+P+3M+15E & 1 & 0 & 0 & 1 & 2 \\
\hline Total & 834 & 3 & 760 & 71 & 902 \\
\hline
\end{tabular}

Source: author 's calculations, data from District 1 Municipality 
With a total investment estimated of 19.380.000 Euro for the rehabilitation of 901 elevators (one is already being modernized), the impact of the program is measuring by the following figures: primary energy consumption saving after thermal rehabilitation and elevators modernization of $211,001 \mathrm{GWh} /$ year (primary energy consumption before thermal rehabilitation and elevators modernization $530.961 \mathrm{MWh} / \mathrm{an}$ and after thermal rehabilitation and elevators modernization $319.960 \mathrm{MWh} /$ year); relative primary energy saving of $40 \% ; \mathrm{CO}_{2}$ decrease; relative $\mathrm{CO} 2$ decrease of $38 \%$.

\section{Conclusions}

Romania has financed actions for increasing the energy efficiency of the buildings through European funds (like regional program and increasing the economic competitiveness), national funds (National Program for increasing the energy efficiency of the multilevel buildings) and other local programs. As more than $70 \%$ of the buildings from Romanian urban area represent multistorey buildings, the national and local authorities must straighten their efforts in developing programs for increasing energy efficiency of these buildings in order to implement the objectives of the strategy for climate changes that request decreasing the CO2 emission by 2050.

One example is the program promoted by the First District of Bucharest that is having 3 components for financing: multilevel buildings, individual houses and domestic elevators modernization. The investments are financed by the European Investments Bank and local budget, representing 350million Euros for multilevel buildings, 60 million Euros for increasing energy performance of individual houses and 19,3 million Euro for elevators, having as main results reducing the level of $\mathrm{CO} 2$ emissions, as well as the savings of more than $30 \%$ of the costs with the maintenance bill. The program is corresponding with the objectives of the Strategy Europe 2020 that requires member states to increase the energy efficiency and consumption of energy from renewable sources.

Furthermore, in line with European legislation framework we recommend having a deep research in identifying and design public policies in renewable energy solution in order to increase clean energies production in the residential domain. The new legal framework with the new concept "prosumer" is creating the proper legal conditions for public authorities in developing new energy efficiency solutions to be implemented for individual houses but also for multilevel buildings.

\section{References}

Biserni C., Valdiserri P., D. D’Orazio, M. Garai, C. Biserni, P. Valdiserri, D. D’Orazio, M. Garai, (2018) Energy Retrofitting Strategies and Economic Assessments: The Case Study of a Residential Complex Using Utility Bills, Energies. 11, 2055, doi:10.3390/en11082055.

Goldenberg J., 2019, The evolution of the energy and carbon intensities of developing countries, Energy policy.

Hamburg A, Kuusk K, Mikola A, Kalamees T, (2020) Realisation of energy performance targets of an old apartment building renovated to nZEB, Energy, doi: https:// doi.org/10.1016/j.energy.2019.116874.

Hamburg A., Kalamees M., 2019 How well are energy performance objectives being achived in renovated apartments buildings in Estonia? Energy \& Buildings 199. 
K.E. Thomsen, J. Rose, O. Mørck, S.Ø. Jensen, I. Østergaard, H.N. Knudsen, N.C. Bergsøe, (2016), Energy consumption and indoor climate in a residential building before and after comprehensive energy retrofitting, Energy Build. 123, 8-16, doi: 10.1016/J.ENBUILD.2016.04.049.

Kuusk K., Kalamees T., (2016). Retrofit cost-effectiveness: Estonian apartment buildings, Build. Res. Inf. 44 doi:10.1080/09613218.2016.1103117.

PICBE | 49

Miller L., Carriveau R., (2019) Energy demand curve variables, An overview of individual and systemic effects, Sustainable Energy Technologies and Assessments 35 172-179

Paiho S., Seppä I.P., Jimenez C., (2015) An energetic analysis of a multifunctional façade system for energy efficient retrofitting of residential buildings in cold climates of Finland and Russia, Sustain. Cities Soc. 15 75-85. doi: 10.1016/J.SCS.2014.12.005.

Directive 2010/31/EU of the European Parliament and of the Council of 19 May 2010 on the energy performance of buildings

Communication from the Commission to the European Parliament, the Council, the European Economic and Social Committee, the Committee of the Regions and the European Investment Bank - A Framework Strategy for a Resilient Energy Union with a ForwardLooking Climate Change Policy

Report from the Commission to the European Parliament, the Council, the European Economic and Social Committee, the Committee of the Regions and the European Investment Bank - Fourth report on the State of the Energy Union

National Plan for Energy Efficiency IV

Report on the progress achieved in the fulfilment of national energy efficiency objectives, 2018 retrieved from: https:/ec.europa.eu/eurostat/cache/infographs/energy/bloc-3a.html, https://www.worldometers.info/co2-emissions/, https://sweden.se/nature/energy-use-insweden/ 